\title{
False positive Wassermann reaction associated with evidence of enterovirus infection
}

\author{
R. A. QUAIFE AND J. V. T. GOSTLING \\ From the Public Health Laboratory, St Mary's General Hospital, East Wing, Milton Road, Portsmouth
}

SYNOPSIS A large proportion of high titre Coxsackie B5 complement-fixation tests was detected among sera giving false positive Wassermann reactions during 1969. Echo virus type 9 proved to be + the prevailing enterovirus and is one of those which induces the formation of antibody to Coxsackie B5. One case of Echo virus type 9 meningitis is presented which produced a false positive Wassermann $\stackrel{N}{\circ}$ reaction and a high titre Coxsackie B5 complement-fixation test. The relationship between Echo윽 virus type 9 infection, Coxsackie complement-fixation test results, and false positive Wassermannreactions is considered significant.

In the spring and summer of 1969 an unusually large number of positive Wassermann reactions was recorded. The reactive sera gave negative results with the Venereal Disease Reference Laboratory (VDRL) slide test and Reiter's protein complementfixation test (RPCFT). The fluorescent treponemal antibody test (ABS) on $\mathbf{3 0}$ of the sera was negative, and on four of these sera the Treponema pallidum immobilization test (TPI) was also negative. The results of these tests and the absence of clinical evidence of syphilis suggests that the Wassermann reactions were non-specific.

\section{Materials and Methods}

The Wassermann reaction was performed by the Whitechapel optimal proportions technique (Price, 1950) using Maltaner cardiolipin antigen. Before testing sera were inactivated at $57^{\circ} \pm 1^{\circ} \mathrm{C}$ for 30 minutes in a water bath, the temperature being checked at the beginning and end of each inactivation. Complement-fixation tests for antibodies to viruses were done by the method of Bradstreet and Taylor (1962).

\section{Results}

During the first 15 weeks of 1969 eight presumptive biological false positives out of a total of 4,257 routine antenatal sera $(0 \cdot 19 \%)$ were detected. From 15 April to 3 June this figure rose to 52 presumptive biological false positives out of 2,230 (2.33\%) and Received for publication 14 July 1970. reached a peak of 17 out of $465(3.66 \%)$ between $6 \stackrel{2}{=}$ and 17 June. Records show an absence of biological false positives out of 533 routine antenatal sera tested during the corresponding period in June 1968.

The figures from antenatal cases are quoted as å cross section of the population. There is no significant $\frac{}{\circ}$ difference when the figures from all types of patients are included.

Many of the positive Wassermann reactions were of a low order, but some were of a high titre. In some instances sera giving approximately $50 \%$ lysis of the sensitized sheep cells at the screen test dilution of 1 in 5 showed partial lysis over a range of dilutions:when titrated. Zoning of lysis was noticed, less 3 . cell lysis occurring in the order of the dilution range.

Storage of the sera at $4^{\circ} \mathrm{C}$ or $-20^{\circ} \mathrm{C}$ was followedo by a rapid deterioration in the Wassermann reactivity. The labile nature of the reaction preventedo reproducible results when sera were tested again Repeated fresh sera from the same patient gaveo variable results; increased, reduced, and unchanged $\sim$ readings were recorded, and some which fluctuated N between negative and positive reactions with several succeeding specimens. The fluctuating results are attributed to the variable periods of time between the specimen being taken from the patient and thes Wassermann testing being performed, thus affecting the labile reactivity.

Virus complement-fixation tests were performed on some of the sera to seek evidence of virus infec $\frac{O}{\mathrm{D}}$ tions as a possible cause of the false positive reactions 2 The results of complement-fixation tests againsk 
Coxsackie B5 virus, which is used in this laboratory as representative of many members of the Enterovirus group, are recorded in Table $I$. These are compared with the results from sera received for routine virus serological investigations. Sera for routine virus studies are not tested by the Wassermann reaction, and were not tested in retrospect as the false positive Wassermann reactive substance had been shown not to survive storage.

\begin{tabular}{|c|c|c|c|c|}
\hline \multirow[t]{2}{*}{ Serum } & \multicolumn{3}{|c|}{$\begin{array}{l}\text { Coxsackie B5 Complement- } \\
\text { fixation Test Titres }\end{array}$} & \multirow[t]{2}{*}{ Totals } \\
\hline & 40 or less & 80 & 160 or greater & \\
\hline $\begin{array}{l}\text { Wassermann reactive sera } \\
\text { Routine virus }\end{array}$ & 6 & 8 & 15 & 29 \\
\hline complement-fixation test & 336 & 9 & 70 & 415 \\
\hline Totals & 342 & 17 & 85 & 444 \\
\hline
\end{tabular}

Table Antibody to Coxsackie B group antigen in Wassermann biological false positive sera compared with those received for routine virus serology

${ }^{1} \chi^{2}=75 \cdot 7$; degrees of freedom $=2$. This implies a proportion of high titres in the Wassermann reactive sera which is very significantly greater than that in the routine virus complement-fixation test sera (significant at the $0.1 \%$ level).

Of 29 Wassermann reactive sera, 23 show a complement-fixation test titre to Coxsackie B5 virus of 80 or greater, 15 being 160 or more. Of 415 sera received for routine virus serology during the period of this survey, 79 show a complement-fixation titre to Coxsackie B5 of 80 or more, 70 being 160 or greater. These figures indicate a correlation between the non-specific Wassermann reactions and Coxsackie B5 titres, significant at the $0.1 \%$ level.

The first isolation of Echo virus 9 in this laboratory in 1969 was made from a specimen received on 11 June. Echo 9 has since proved to be the prevailing enterovirus for this season in this area and is one of those which induces the formation of antibody to Coxsackie B5. The high Coxsackie B5 complementfixation test antibody titres were suggestive of Echo virus infection in view of the isolation rate of this agent.

\section{Illustrative Case}

Specimens were received from patient $\mathrm{V}$, a man aged 30 years, who had been admitted to hospital in July 1969 with meningeal symptoms. A routine Wassermann test on admission was positive to a titre of
160; the VDRL slide test, Reiter protein complement-fixation test, FTA-ABS, and TPI tests were negative. The Coxsackie B5 complement-fixation test titre was 320 . The cerebrospinal fluid had a cell count of 20 leucocytes per cmm, lymphocytes and polymorphonuclear cells being approximately equal in numbers. Protein was $40 \mathrm{mg}$ per $100 \mathrm{ml}$ and sugar $70 \mathrm{mg}$ per $100 \mathrm{ml}$. Echo virus type 9 was isolated from the cerebrospinal fluid.

\section{Discussion}

Enterovirus infections occur annually without the large scale effect seen on routine Wassermann tests in 1969. The enterovirus isolated most frequently in this laboratory from June to September 1969 was Echo virus type 9. There were a large number of Echo virus type 9 isolations in 1964, but no significant increase in non-specific Wassermann reactions was noticed in that year.

The Coxsackie B5 virus complement-fixation test antigen is produced from tissue culture material. The particle concentration is low and the harvested material is used as an antigen at a low dilution. The tissue cell material present, although of human origin and in serum-free medium, could have acted as a non-specific antigen analogous to the Wassermann antigen. This factor was not investigated.

Despite this possibility, it is suggested that there is a correlation between the very large number of hightitre Coxsackie B5 virus complement-fixation test results and the false positive Wassermann sera in 1969. The one case of Echo virus type 9 meningitis reported here is an example of this correlation between false-positive Wassermann reaction, Coxsackie B5 complement-fixation test results, and the Echo virus type 9 infection.

We thank Dr A. E. Wilkinson, Director of the Venereal Disease Reference Laboratory, for the fluorescent treponemal antibody and treponemal immobilization tests reported in this paper, Miss H. E. Mogford for statistical advice, and Mr B. Parsons and Miss B. Meldrum for technical assistance.

\section{References}

Price, I. N. O. (1950). Complement-fixation technique III; The Wassermann reaction. Brit. J. vener. Dis., 26, 172-173.

Bradstreet, C. M. P., and Taylor, C. E. D., (1962). Technique of complement-fixation test applicable to the diagnosis of virus disease. Mth. Bull. Minist. Hlth Lab. Serv., 21, 96-104. 